$\mathrm{DE}$

M E D I C I N A

T R O P I C A L

$\mathrm{DE}$

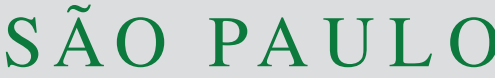

JOURNAL OF THE SÃO PAULO INSTITUTE OF TROPICAL MEDICINE

'Universidade Estadual de Campinas, Laboratório de Pesquisa Aplicada em Dermatologia e Bartoneloses, Campinas, São Paulo, Brazil

${ }^{2}$ Instituto Federal de Ciência e Tecnologia de São Paulo, Câmpus Capivari, Capivari, São Paulo, Brazil

${ }^{3}$ University of Minnesota, Department of Dermatology, Minneapolis, Minnesota, USA

${ }^{4}$ University of Minnesota, Department of Medicine, Division of Hematology, Oncology and Transplantation, Minneapolis, Minnesota, USA

${ }^{5}$ Universidade Estadual de Campinas, Departamento de Dermatologia da Faculdade de Ciências Médicas, Campinas, São Paulo, Brazil

Correspondence to: Gislaine Vieira Damiani

Instituto Federal de Ciência e Tecnologia de São Paulo, Campus Capivari, Avenida Doutor Ênio Pires de Camargo, 2971, São João Batista, CEP 13360-000, Capivari, SP, Brazil

E-mail: gislainevieirad@gmail.com

Received: 16 June 2020

Accepted: 16 September 2020

\section{Bartonella henselae infection induces a persistent mechanical hypersensitivity in mice}

\author{
Gislaine Vieira-Damiani ${ }^{(1,2}$, Amanda Roberta de Almeida ${ }^{(1}$, Marilene Neves \\ Silva ${ }^{\circledR}$, Bruno Groseli Lania ${ }^{\circledR}$, Tânia Cristina Benetti Soares ${ }^{\circledR 1}$, Marina \\ Rovani Drummond ${ }^{\circledR 1}$, Karina A. Lins ${ }^{\circledR 1}$, Marna Ericson ${ }^{\circledR 3}$, Kalpna Gupta ${ }^{\circledR 4}$, \\ Paulo Eduardo Neves Ferreira Velho ${ }^{1,5}$
}

\section{ABSTRACT}

Bartonella spp. are re-emerging and neglected bacterial pathogens. The natural reservoirs for several species of this genus are domestic animals such as cats and dogs, the most common pets in the USA and Brazil. Some cat studies suggest that the infection is more prevalent in tropical and poverty-stricken areas. These bacteria were associated with a wide spectrum of clinical manifestations: fever of unknown origin, endocarditis, angiomatosis, chronic lymphadenopathy, hepatitis, fatigue, paresthesia and pain. Our group has already demonstrated that $B$. henselae-infected sickle cell disease mice present with hyperalgesia. We hypothesized that even immunocompetent mice infected by $B$. henselae would show an increased and persistent mechanical sensitivity. Five ten-week old male BALB/c mice were intraperitoneally inoculated with a $30 \mu \mathrm{L}$ of suspension containing $10^{4} \mathrm{CFU} / \mathrm{mL}$ of $B$. henselae, while five others were inoculated with an equal volume of saline solution. Four days after bacterial inoculation, the mechanical paw withdrawal threshold was measured using von Frey filaments in all animals, for five consecutive days. The infected animals showed hypersensitivity to mechanical stimuli for five consecutive days. The present study has demonstrated that $B$. henselae infection induces persistent mechanical hypersensitivity, a signal consistent with pain.

KEYWORDS: Bartonella. Hypersensitivity. Mice. Hyperalgesia.

\section{INTRODUCTION}

Bartonella spp. are Gram-negative bacilli with worldwide distribution that can cause a wide range of clinical manifestations and can be fatal, especially in immunodeficient patients ${ }^{1}$. Among all Bartonella species, Bartonella bacilliformis, Bartonella quintana and Bartonella henselae are the most common cause of human infections ${ }^{2}$. $B$. henselae is a zoonotic pathogen transmitted to humans by fleas and ticks. Cats are main carriers of this infection ${ }^{3}$. The $B$. henselae can infect erythrocytes, macrophages, endothelial cells, and pericytes ${ }^{4,5}$. B. henselae has been associated with asymptomatic infection in humans including blood donors ${ }^{6}$. This species is the agent of Cat Scratch Disease (CSD) and may induce fever of unknown origin, endocarditis, angiomatosis, chronic lymphadenopathy, hepatitis, fatigue, paresthesia, and pain in infected hosts ${ }^{7}$.

Our group has already demonstrated that $B$. henselae-infected sickle cell disease mice present with hyperalgesia ${ }^{8}$. Therefore, the aim of this study was to evaluate if $B$. henselae-infected immunocompetent mice would show persistent mechanical hypersensitivity. 


\section{MATERIALS AND METHODS}

\section{Animals}

All procedures were performed in accordance with the policies in the Guide for the Care and Use of Laboratory Animals, after approval from the Committee of the Institution of Animal Care and Use (protocol No 2848-1). All possible measures were taken by the involved scientists to minimize animal suffering during the experiments. Ten-week-old male BALB/c mice, weighing 22-23 g, were maintained in a 12-hour light/dark cycle room in a climate-controlled environment, with access to food and water ad libitum. Animals were provided by the UNICAMP Multidisciplinary Center for Biological Research.

\section{Bacterial suspension and infection}

The bacterial suspension was aseptically prepared with $\mathrm{NaCl} 0.9 \%$ and $10^{4}$ Colony Forming Units (CFU) of $B$. henselae / mL (Houston 1 strain, American Type Culture Collection, Rockville, MD, USA). Five mice were intraperitoneally inoculated with a $30 \mu \mathrm{L}$ of this suspension and five control mice received an equal volume of $\mathrm{NaCl} 0.9 \%$.

\section{Mechanical nociceptive threshold}

To assess sensitivity to a mechanical stimulus, paw withdrawal threshold was determined using von Frey filaments (27) (1601C, Life Science Instruments ${ }^{\circledR}$ ), with precision ranging between 0.1 to $80 \mathrm{~g}$ of weight. Each animal was placed into an individual transparent acrylic box $(9 \mathrm{~cm}$ $\times 9 \mathrm{~cm} \times 13 \mathrm{~cm}$ ) with a wire mesh platform floor made with non-malleable $1 \mathrm{~mm}$ thick wire. Mirrors placed at $30 \mathrm{~cm}$ below the experimentation boxes allowed visualization of the paw sole. Mice were placed in these individual boxes 30 minutes before the experiment for acclimatization. The von Frey filaments were applied with progressive pressure into the mid plantar surface of a left hind paw through the mesh floor until the animal lifted up its paw.

We tested the animals prior to and after infection with B. henselae. Animals were tested for five days, from day four after inoculation until day eight. The stimulus was repeated six times, with five-minute intervals, and similar measures were observed. . Two different researchers individually the behavior of each animal. (GVD, MNS).

\section{Statistical analysis}

Data are expressed as mean \pm standard error. Von Frey tests were analyzed using the Statistical Analysis System for Windows (SAS 9.4, SAS Institute Inc., Cary, NC, USA). The means were compared with using ANOVA Repeated Measures and data were transformed into ranks. Differences were considered significant at $p<0.05$.

\section{RESULTS}

\section{Von Frey test}

No differences were noted in sensitivity in the control group ( $p=0.5014)$. Paw withdrawal thresholds were lower in infected mice compared to control group $(p<0.05)$ from the $4^{\text {th }}$ day after infection and after. Table 1 shows the mean, median and standard deviation (SD) of all measures. Figure 1 shows the intensity of mechanical sensitivity,before and after $B$. henselae infection.

Table 1 - Von Frey test values of Bartonella henselae-infected mice and controls. Time was expressed in days.

\begin{tabular}{ccccc}
\hline & Mean & Median & SD & pvalue \\
\hline $\begin{array}{c}\text { Before } \\
\text { Control }\end{array}$ & 9.47 & 9.47 & 1.64 & \\
Infected & 9.80 & 9.37 & 1.32 & 0.6873 \\
$\mathbf{4}^{\text {th }}$ day & & & & \\
Control & 8.94 & 8.93 & 0.52 & \\
Infected & 7.77 & 8.10 & 0.82 & 0.0158 \\
$\mathbf{5}^{\text {th }}$ Day & & & & \\
Control & 8.79 & 8.63 & 1.08 & \\
Infected & 7.08 & 7.13 & 0.21 & 0.0093 \\
$\mathbf{6}^{\text {th }}$ day & & & & \\
Control & 9.79 & 9.70 & 0.70 & \\
Infected & 6.95 & 6.67 & 0.54 & 0.0001 \\
$\mathbf{7}^{\text {th }}$ day & & & & \\
Control & 9.43 & 9.53 & 0.44 & 0.0010 \\
Infected & 8.06 & 7.97 & 0.49 & \\
$\mathbf{8}^{\text {th }}$ day & & & 0.9015 \\
Control & 9.26 & 8.83 & 0.92 & \\
Infected & 7.71 & 7.70 & 0.20 & 0.0015 \\
\hline
\end{tabular}

\section{DISCUSSION}

In humans, $B$. henselae infection has been associated with persistent back, chest, arms, shoulder, joint and peripheral neuropathic pain ${ }^{9}$. Intermittent headache and bone pain have also been reported ${ }^{9}$. Many patients have no known immunodeficiency ${ }^{10}$. As a translational way to analyze if $B$. henselae can be related to pain in infected immunocompetent organisms, we observed if 


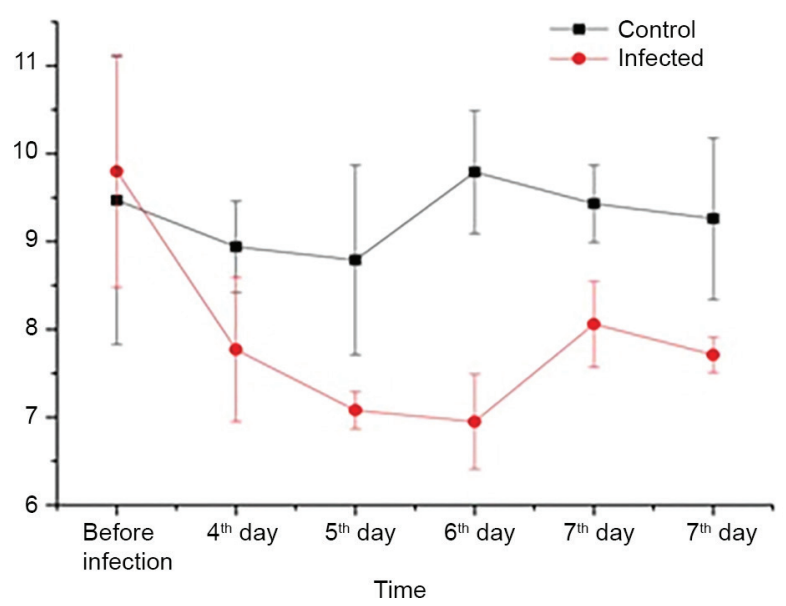

Figure 1 - Y-axis: Paw pressure threshold (g). Infected animals had a decreased intensity of nociception. Mechanical nociceptive threshold was evaluated before experimentation and for five consecutive days after $B$. henselae infection. All data are expressed as mean \pm SD for the five mice.

immunocompetent mice have increased sensitivity after experimental $B$. henselae infection.

Bacterial infection can produce pain in mice ${ }^{11}$. We have already demonstrated that $B$. henselae induced hyperalgesia in sickle cell disease mice after intraperitoneal inoculation of a bacterium suspension ${ }^{8}$. As pain can be related to behaviors, ${ }^{8,12}$ we used the von Frey test to analyze the sensitivity in infected animals infected by $B$. henselae, and we observed that infected immunocompetent mice show more sensitivity than uninfected ones, for five consecutive days beginning on day four after the infection.

The pain mechanism that can be triggered by $B$. henselae remains unclear. Understanding the molecular and cellular mechanisms of infection and the host immune response is crucial to clarify $B$. henselae pathophysiology. Immune cells stimulated by different infectious pathogens increase the production of endothelin- $1^{13}$, which plays an important role in the pathogenesis of infectious diseases ${ }^{14}$. Because $B$. henselae infects endothelial cells, these cells may produce and secrete endothelin- 1 . This could be a mechanism involved in $B$. henselae infection related pain.

In summary, the present study demonstrated that $B$. henselae infection induces a persistent mechanical hypersensitivity, a signal consistent with pain in immunocompetent mice.

\section{ACKNOWLEDGMENTS}

We are grateful to Professor Almicar Parada from University of Campinas (UNICAMP) Biology Institute, for his permission to use his facilities, and to Daniele Masselli Rodrigues Demolin PhD., for providing research infrastructure to maintain the animals at the UNICAMP Multidisciplinary Center for Biological Research.

\section{AUTHORS' CONTRIBUTIONS}

GVD and AAR: carry out the experiments, conceived and planned the experiments, wrote the article; MNS, BGL, TCBS, MRD, KAL: helped to carry out the experiments; PENFMEE, KG: contributed to the design and implementation of the research; PENF: supervise the Project, contributed to the design and implementation of the research, to the analysis of the results. All authors contributed to the final version of the manuscript.

\section{CONFLICT OF INTERESTS}

None to declare.

\section{FUNDING}

This study received financial support from Support Fund for Research, Teaching and Extension - FAEPEX, (2014/519.294); National Council for Scientific and Technological Development - CNPq (PENFV grant $\mathrm{N}^{\circ}$ 301900/2015-9 and MRD grant $N^{\circ}$ 159717/2013-2).

\section{REFERENCES}

1. Biswas S, Rolain JM. Bartonella infection: treatment and drug resistance. Future Microbiol. 2010;5:1719-31.

2. Rolain JM, Brouqui P, Koehler JE, Maguina C, Dolan MJ, Raoult D. Recommendations for treatment of human infections caused by Bartonella species. Antimicrob Agents Chemother. 2004;48:1921-33.

3. Breitschwerdt EB, Maggi RG, Chomel BB, Lappin MR. Bartonellosis: an emerging infectious disease of zoonotic importance to animals and human beings. J Vet Emerg Crit Care (San Antonio). 2010;20:8-30.

4. Dehio C, Meyer M, Berger J, Schwarz H, Lanz C. Interaction of Bartonella henselae with endothelial cells results in bacterial aggregation on the cell surface and the subsequent engulfment and internalisation of the bacterial aggregate by a unique structure, the invasome. J Cell Sci. 1997;110:2141-54.

5. Pitassi LH, Cintra ML, Ferreira MR, Magalhães RF, Velho PE. Blood cell findings resembling Bartonella spp. Ultrastruct Pathol. 2010;34:2-6.

6. Pitassi LH, Diniz PP, Scorpio DG, Drummond MR, Lania BG, Barjas-Castro ML, et al. Bartonella spp. bacteremia in blood donors from Campinas, Brazil. PLoS Negl Trop Dis. 2015;15:e0003467.

7. Maggi RG, Ericson M, Mascarelli PE, Bradley JM, Breitschwerdt 
EB. Bartonella henselae bacteremia in a mother and son potentially associated with tick exposure. Parasit Vectors. 2013;6:101.

8. Almeida AR, Vieira-Damiani G, Silva MN, Grosseli BG, Soares TC, Drummond MR, et al. Bartonella henselae infection in sickle cell disease mice is associated with hyperalgesia. Vector Borne Zoonotic Dis. 2019;19:102-5.

9. Boggs SR, Fisher RG. Bone pain and fever in an adolescent and his sibling. Cat scratch disease (CSD). Pediatr Infect Dis J. 2011;89:93-4.

10. Zenone T. Systemic Bartonella henselae infection in immunocompetent adult presenting as fever of unknown origin. Case Rep Med. 2011;2011:183937.
11. Chiu IM, Heesters BA, Ghasemlou N, Hehn CA, Zhao F, Tran $\mathrm{H}$, et al. Bacteria activate sensory neurons that modulate pain and inflammation. Nature. 2013;501:52-7.

12. Lei J, Benson B, Tran H, Ofori-Acquah SF, Gupta K. Comparative analysis of pain behaviours in humanized mouse models of sickle cell anemia. PLoS One. 2016;11:e160608.

13. Dietmann A, Lackner P, Helbok R, Spora K, Issifou S, Lell B, et al. Opposed circulating plasma levels of endothelin-1 and C-type natriuretic peptide in children with Plasmodium falciparum malaria. Malar J. 2008;7:253.

14. Freeman BD, Machado FS, Tanowitz HB, Desruisseaux MS. Endothelin-1 and its role in the pathogenesis of infectious diseases. Life Sci. 2014;118:110-9. 